\title{
Lost and Found in Limerick: Exploring the Experiences of Migrants Who Have Made Limerick Their Home
}

\author{
Michelle Ryan
}

\begin{abstract}
This chapter examines the lived experiences of asylum seekers and refugees who have made Limerick (a small city in the Midwest of Ireland) their home over the past decade. The emphasis was originally on both cultural bereavement (what migrants leave behind) and cultural gain (what tangible supports they have found in Limerick that enable them to form new identities and move forward with their lives). The study focuses particularly on those individuals who have lived in, or are currently living in, a system called Direct Provision and the challenges that they face.
\end{abstract}

\section{Keywords}

migrants - asylum seekers - refugees - cultural bereavement - direct provision - loss and grief

\section{1 \\ Introduction}

This study explores the lived experience of migrants who have settled in Limerick in the last ten years to gain an understanding of their situation in two respects: (i) what they have lost (specifically cultural bereavement) and also (ii) what they found in their new home in Limerick to help them build new identities and communities. As the research progressed, the wider global displacement of people featured consistently throughout the media. The picture of Aylan Kurdi, the 3 year old Syrian boy whose body washed up on the beach in Turkey went viral within days of being posted 
online. ${ }^{1}$ People of all backgrounds, nationalities and religions mourned the child's death. Even locally in County Limerick, a project was set up to offer accommodation to Syrian refugees in a 'pledge a bed' campaign. ${ }^{2}$ This refocused the research project to migrants who had come to Limerick and were seeking asylum or refugee status. There is little literature published on this topic because it is very new to the Irish context, so this research may prove timely. The main themes of existing migrant literature addresses psychological impact, children in direct provision and trauma. ${ }^{3}$ This research will investigate the lived experience of individuals who reside in Direct Provision. This is the system used in Ireland to deal with asylum seekers and refugees. People are accommodated in residential institutions, where they can remain for many years. They are prohibited from working and from cooking for themselves and individuals share living space, whole families occupying one room.

\section{Key Objectives and Methodology}

This chapter will review the background to immigration in Ireland, then examine the system that is called Direct Provision, which Ireland uses to manage asylum seekers and refugees. Then it will discuss the situation from an NGO perspective and finally move on to the emerging themes from the research. The main purpose is to review the lived experience of migrants. I carried out a pilot study before meeting the five participants who were willing to share their story with me. Some of these I contacted through my supervisor at the Limerick Institute of Technology and others I met through an NGO based in Limerick called Doras Luimni (I will talk about this organisation further in the

1 Anne Bernard and Karam Shaloumi, 'Image of Drowned Syrian, Aylan Kurdi, 3, Brings Migrant Crisis into Focus', New York Times, 2015, accessed 6 June 2016, https://www.nytimes .com/2015/og/o4/world/europe/syria-boy-drowning.html

2 Anne Sheridan, '45o Beds in Limerick Pledged to Refugees', Limerick Leader, September 2015, accessed 30 September 2016 https://www.limerickleader.ie/news/local-news/196o2o/45o -beds-in-Limerick-pledged-to.html

3 Dermot A. Ryan, Ciarán A. Benson, and Barbara A. Dooley, 'Psychological Distress and the Asylum Process', The Journal of Nervous and Mental Disease 196.1 (2008): 37-45; Alastair Christie, "Unsettling the "Social" in Social Work: Responses to Asylum Seeking Children in Ireland', Child Family Social Work 8.3 (2003): 223-231; Bryan Fanning, Angela Veale, and Dawn O'Connor, Beyond the Pale: Asylum-Seeking Children and Social Exclusion in Ireland (Dublin: Irish Refugee Council, 2001); Theophilus Ejorh, 'Modern African Migrations to Ireland: Patterns and Contexts', Journal of Ethnic and Migration Studies 38.4 (2012): 577-593. 
chapter.) One of the challenges was to find participants, because people are reluctant to talk for many reasons: they don't wish to revisit traumatic experiences, they don't want to appear to be complaining about their circumstances for fear it will have a negative impact on their asylum seeking process. Also some participants are simply tired of telling their story. The people I met are either currently residing in direct provision or have previously lived there. Their countries of origin include Somalia, Tanzania, Uganda and Zimbabwe. The initial interviews took place in a neutral venue and took approximately between thirty minutes to one hour.

\section{Background}

Since the early 200o's Ireland has experienced an increase in inward migration, mainly due to what was termed 'The Celtic Tiger'. This was an economic boom that began in the late 1990s, and has been attributed to a number of factors including: foreign direct investment, an essentially flexible workforce, and social partnerships that created a stable working environment. ${ }^{4}$ This encouraged many Europeans and people of other nationalities to migrate to Ireland. Limerick, the fourth largest city in Ireland (with approximately 190,ooo inhabitants) currently hosts a number of those migrants. ${ }^{5}$ They are predominantly from EU member countries in Eastern Europe (such as Poland and Lithuania), but also comprise a number of other nationalities.

This is the first experience Ireland has had of inward migration on such a scale. For the past two centuries migration has been distinctly outward. Approximately ten million people left Ireland during those 200 years, many people forced by famine from their homes to the UK and USA. ${ }^{6}$ It could be argued that, as members of a nation with such a history, the Irish people should have empathy toward migrants. Forced migration has become internationally even more evident today. Due to the rate of climate change, natural disasters and conflict, international communities are seeing a dramatic increase in human

4 O'Hearn, Denis. 2003. "Macroeconomic Policy In The Celtic Tiger: A Critical Reassessment." In The End Of Irish History? Critical Approaches To The Celtic Tiger, 1st ed., 34-55. Manchester: Manchester University Press.

5 'Document title', CSO - Central Statistics Office, accessed 27 May 2016, https://www.cso.ie/ en/media/csoie/census/documents/census2ol1profile6/Profile_6_Migration_and_Diversity _entire_doc.pdf

6 Kevin Kenny, 'Diaspora and Comparison: The Global Irish as a Case Study', Journal of American History 9o.1 (2003): 134-162. 
displacement and migration. ${ }^{7}$ Conflict-induced forced migration is at the highest level ever recorded, with an estimated $60+$ million people classed as refugees or internally displaced. ${ }^{8}$

A tiny fraction of those displaced or seeking asylum currently reside in Ireland - the numbers coming to just under 8,ooo people according to a working group report to the Irish government last year. ${ }^{9}$ While $54 \%$ of asylum seekers live in the community, the remaining $46 \%$ live in the direct provision system, of which the Irish public had little knowledge until recently. ${ }^{10}$

\section{Direct Provision}

Direct provision is the responsibility of the Reception and Integration Agency (RIA). The agency was formed in 1982 and is part of the Irish Naturalisation and Immigration Service (INIS), which in turn is a division of the Department of Justice and Equality. The RIA is the organisation charged with providing accommodation and food under a Direct Provision System to asylum seekers while their application for international protection is being processed. According to the RIA:

Direct provision is a means of meeting the basic needs of food and shelter for asylum seekers directly while their claims for refugee status are being processed rather than through full cash payments. Direct provision commenced on 10 April, 2000 from which time asylum seekers have received full board accommodation and personal allowances of €19.10 per adult and €9.6o per child per week.11

7 Marion Couldrey and Maurice Herson, 'Page/document title', Forced Migration Review, accessed 4 May 2016, http://www.fmreview.org/sites/fmr/files/FMRdownloads/en/ climatechange-disasters.pdf

8 Niels Harild, 'Forced Displacement: A Development Issue with Humanitarian Elements', Forced Migration Review, accessed 19 June 2016, http://www.fmreview.org/solutions/ harild.html

9 Working Group 2015 was a group set up to review the system of direct provision in Ireland. It was established by the government and membership of the group consisted of a range of backgrounds including UNHCR, non-governmental organisations, protection applicants and academia.

10 Liam Thornton, “\#DirectProvision15: 15 Years of Direct Provision in Ireland - Human Rights in Ireland', Human Rights in Ireland, 2015, accessed 4 June 2016, https://liamthornton .ie/2015/04/o6/directprovision15-15-years-of-direct-provision-in-ireland-a-timeline/

11 Reception and Integration Agency (RIA) Ireland, accessed 4 June 2016, http://www.ria.govie/ 
Individuals in direct provision endure endless periods of inactivity, often leading to depression, social isolation and poverty. Typically the centres are placed outside local towns, making the possibility of integrating with the community fraught with practical obstacles, while increasing othering and keeping the issue of migrants hidden. Asylum seekers are not allowed to work in Ireland, cannot participate in any form of study, and are even prohibited from cooking for themselves. They spend the majority of their time with nothing to do, nowhere to go, and without financial means. This level of inactivity and 'waiting', as one of my interviewees termed it, often leads to 'frustration, loneliness and depression'. The Irish Refugee Council, as well as many non-governmental organisations who represent asylum seekers, are openly critical of this system and advocate a more humane arrangement.

\section{$5 \quad$ Doras Luimni}

This research is closely linked to an organisation called Doras Luimni. ${ }^{12}$ Doras Luimni is an NGO based in Limerick that offers direct support services to migrants and refugees in the Limerick and general Midwest region (that includes the counties of Clare, Tipperary and Laois). Their declared mission is to support the human rights of migrants through advocacy, integration initiatives and campaigns at both local and national levels. They report that much of their work currently centres on helping asylum seekers to navigate the immigration system and gain access to social welfare, housing and employment. They also administer campaigns to influence policy and engage policy makers. Through my relationship with Doras, they have helped recruit volunteers for this research, and I will be enlisting the help of these interviewees to recruit more participants through 'snowball' or purposive sampling. It may well be the case that the reluctance of individuals to participate is mainly due to fear, as my pilot study participant suggested, but also due to interview fatigue. It is often the same people who offer to be interviewed by researchers doing this type of phenomenological qualitative study. At a conference workshop at the University of Limerick one activist confirmed this, by suggesting that the same people are getting tired of doing interviews and not seeing results or outcomes. ${ }^{13} \mathrm{He}$

\footnotetext{
12 Helen O'Grady, 'Barriers to the Labour Market for Refugees and Persons with Leave to Remain in Limerick', Dorasluimni.org, 2008, accessed 4June 2016, http://dorasluimni.org/ wp-content/uploads/pdf/publications/barrierstolabour.pdf

13 Stephen Ng'ang'a, 'Making History' (Paper presented at University of Limerick, Limerick, July 2016). Workshop: Engaging with refugees: Disseminating Social Scientific Research,
} 
then appealed to academics and researchers to find new ways of disseminating their research so that the wider public has access and that policy making can become more enlightened.

\section{$6 \quad$ Emerging Themes}

At the time of writing this chapter I am still in the process of recruiting participants and completing semi-structured interviews, and have yet to complete an in-depth thematic analysis. However some themes are clearly emerging:

A: Migrant experience of direct provision as a form of 'prison'

B: Lack of trained professionals in direct provision

C: Ireland not the chosen destination

D: Unspoken and unacknowledged grief and fear

E: Ambiguous loss

\section{A: $\quad$ Migrant Experience of Direct Provision as a Form of Prison}

Each of the participants referred to direct provision centres (there are 34 in the country) as 'prison'. For many years they had to sign a register every day to confirm they were present. Following an application to the High Court in 2014 by two asylum seekers in Galway, the ruling did not find direct provision unlawful but did acknowledge that some of the procedures in the direct provision centres were unlawful. These included the lack of visitation rights, unannounced room inspections and the requirement to sign in. ${ }^{14}$

The direct provision centres are in the words of Anna:

Like open prison camps, now we don't have to sign up but until last year you had to go in every day to reception to sign in to say that you are in the centre but now you know the room keys are electronic so now that's how they keep track of you. If you're not in the room for more than 3 days they give away your room so you have no place to live anymore. ${ }^{15}$

to Increase Impact on Practise, Policy and Community, University of Limerick, July 6, 2016.

14 Ruadhan Mac Cormaic, 'Direct Provision System does not breach human rights, court rules', The Irish Times, accessed 30 September 2016, https://www.irishtimes.com/news/ crime-and-law/courts/direct-provision-system-does-not-breach-human-rights-court -rules-1.2001017

15 Anna - Participant one renamed to maintain anonymity, living in Direct Provision 3 years, age 32 . 
This was the experience of one asylum seeker. He went to visit a friend in another centre and access to his own room was consequently removed. This participant felt that he had been labelled a troublemaker and was forced to move to another facility. Another participant, Frank, echoed this sentiment of a prison-like experience,

I see it was a crime to come and seek asylum in this country, you see by in the eyes of the department of justice I believe it is a crime 'cos we are just kept in that ... look it's better to be kept in prison because you know your fate even if you have some difficulties in prison you know how to sort yourself inside there until you come out and gain your freedom again but in this one there is nothing it's even worse. ${ }^{16}$

He goes on to describe the conditions in his facility, which also highlights his experience as an 'Other' - a guest in the country, not feeling at home,

... one you are forced to eat the food, look I am not Irish, the food is terrible, so terrible, if I had enough time I would show you some photos of the food that we eat, it's very terrible you know people each and every time have leftovers after the following day so when you cook it again the following day it gets not food at all and we are forced to eat that, you understand we are forced to eat that. ${ }^{17}$

Another participant talked about hiding rice cookers in the ceiling space above their rooms as they are not allowed to cook. If the rice cookers are found during room searches they are confiscated. Luckily rice cookers are not terribly expensive, this lady added '..they only cost nineteen euros so it's not so expensive to replace.'18 This is quite ironic when the total income for that person is nineteen euros per week.

\section{B: $\quad$ Lack of Trained Professionals}

Throughout the NGO literature and reports published by these organisations who advocate for refugees and asylum seekers, the topic of mental health is often discussed. The detrimental psychological effects on those who remain

16 Frank - Participant two renamed to maintain anonymity, living in Direct Provision 6 years, age 3 .

17 Ibid., 16.

18 Ibid., 15 . 
in this system for long periods of time can be significant. ${ }^{19}$ The direct provision service is tendered through local authorities and there is no requirement to have professionals qualified in social care, psychology, or health, or anyone who would be in a position to support people who may have been through considerable trauma. This theme also emerged from my discussions. In particular, Frank concurs:

The worst part is the staff put in place there doesn't have patience or training to deal with any of it. They don't have the personality or the skill to handle people, they are not qualified at all. ${ }^{20}$

People who have been displaced through forced migration, who are very likely suffering from post-traumatic stress, are often then forced to cohabit in an unsafe environment. Cultural and religious clashes occur in the centres, as people with different religious backgrounds are forced to share the same limited space. This was the experience of one of the interviewees, James:

... you know I am 35 years and staying in with three others that you don't even know they are coming from its actually awful, there is no privacy in the house, we are different religion each other Muslims and Christians and we know exactly there is tension out there between religion so you see its very difficult. ${ }^{21}$

\section{C: $\quad$ Lack of Choice in Ireland as a Destination}

One participant said he thought he was in London for a few days before he realised he had arrived in Dublin. He had never heard of Ireland before he learned where he was. Another said whoever organised her passage out of her home country chose what flights were immediately available to them based on the papers that she held. She fled the country with her children who were in their shorts and t-shirts and arrived to a very cold November day in Ireland with no warm clothing to put on the children. This finding should help to dispel some of the myths and rumours that abound in the narrative around migrants: for

\footnotetext{
19 Ibid., 12.

$20 \quad$ Ibid., 17.

21 James - Participant three renamed to maintain anonymity, living in Direct Provision 6 years, age 35 .
} 
example that they are coming to Ireland for social welfare. Many asylum seekers are not interested in social welfare: they want to work.

\section{D: Unspoken and Unacknowledged Grief and Fear}

Throughout the process of phenomenological interviewing there is a lot left unsaid. There are several possible explanations for this. Perhaps during a first meeting with a researcher, people are wary of how much information they share; they may be afraid to say too much about their living conditions or their past experience. A campaign manager and human rights advocate at Doras Luimni gently guided me before I met participants. She suggested that it would be morally correct to refrain from asking an asylum seeker why they had come to Limerick. That was confirmed by my pilot study participants over a number of meetings. It is not possible to know before meeting an asylum seeker what they have been through or what trauma they have experienced before arriving in Limerick.

The objective of phenomenological research is to understand the lived experience. Apropos to this task, we might recognise that silence forms part of human interaction and communication as much as speaking does. When a person chooses silence as part of their own discourse, the researcher must be aware of it and explore it, in order to represent it correctly. Silence was part of my interaction with the participants and I wanted to be respectful of that phenomenon in the exchange. Dienske suggests that when human beings experience the unspeakable it may be beyond a person's linguistic competence to speak of it..2 In the present study, this difficulty is compounded by the fact that English is not the first language of my participants. Another factor to consider is the imbalance of power which plays a part here; I became mindful of my own position of privilege, being a white person in a white society. Also being female, gender is an issue. Many of the asylum seekers come from societies which hold differing views on a woman's place in society.

\section{E: Ambiguous Loss}

'Ambiguous loss is a loss that remains unclear. ${ }^{23}$ A further theme to emerge from the research which is relevant here is ambiguous loss. Each of the participants refer to losing loved ones, family members who have disappeared and also leaving their family behind. When such relationships are unclear and there is no way to attain closure, the vagueness causes anxiety and grief which

\footnotetext{
22 Max Van Manen, 'On the Epistemology of Reflective Practice', Teachers and Teaching 1.1 (1995): xx, doi:10.1080/1354060950010104.

23 Boss, Pauline. 1999. Ambiguous Loss. 1st ed. Cambridge, Mass.: Harvard University Press.
} 
becomes very complicated. ${ }^{24}$ According to Boss, 'ambiguous loss always results from war and violence. ${ }^{25}$ This reinforces the trauma that an asylum seeker experiences.

Boss suggests there are two types of loss: physical and psychological. Both are experienced by asylum seekers and refugees. Physical loss, as the term suggests, is when someone is no longer physically present. ${ }^{26}$ For refugees, that represents the families they have left behind. Psychological loss, on the other hand, affects the asylum seeker vis-à-vis their identity that they have lost; their sense of self; having left their homes, their careers, their dreams. ${ }^{27}$ I intend to examine whether or not ambiguous loss theory is a good model to assess the migrants' situation. Understanding this may help by providing psychologists or advocacy groups with a framework within which to build more beneficial interventions.

At a conference in the University of Limerick in July 2016, attended by activists, academics and $\mathrm{NGO} \mathrm{s}{ }^{28}$ former refugees spoke about the shame of admitting to being a refugee. One participant told me she could not tell her family in Africa that she was a refugee or that she was part of the system or living in direct provision. She wanted to maintain her identity through them holding onto their image of a previous version of her. The notion of migrants losing their self-identity is potentially another area worthy of exploration.

\section{Conclusion}

The study set out to explore migrants' experience in Limerick. The research evolved from exploring narratives about the developing multicultural aspects of Limerick city to focus on the experience of asylum seekers and refugees in the system called direct provision. The findings add to our knowledge that asylum seekers have little or no voice, so the objective now is to bring the voice of the asylum seeker to the public. It is too early to discuss the cultural bereavement or cultural gain experienced by migrants. The trauma they have to endure before being displaced - being exposed to horrors like torture, persecution,

\footnotetext{
24 Ibid., 22.

25 Ibid., 23.

26 Ibid., 20.

27 Ibid., 20.

28 Conference: Agents through Time: How Do People "Make History"? Social Psychological \& Historical Research into Collective Memories, Social Identities \& Intergroup Relations. Final Cost Action IS1205 Conference, University of Limerick, Ireland. July 7-8, 2016. Workshop: Engaging with refugees: Disseminating Social Scientific Research, to Increase Impact on Practice, Policy and Community, University of Limerick, July 6, 2016.
} 
rape, or starvation - is challenging enough, without exposing a fragile human being to what can be seen as the ill treatment of direct provision. Overcoming the difficulties encountered and the unsettling experiences they have suffered shows a depth of resilience which is also yet to be explored. Agencies and NGO s are not equipped to address the developmental needs of individuals in the direct provision system in Ireland and yet it has been allowed to continue for sixteen years with no indication of the process changing. Further research is clearly needed, and new ways of sharing and disseminating the data gathered, and the conclusions reached, might productively be explored. Educating people about other cultures and changing the narrative and discourse about globalisation will plausibly benefit us all. As one of the participants in this research perceptively said: 'there is only one race, the human race'.

\section{Bibliography}

Boss, Pauline. Ambiguous Loss Learning to Live with Unresolved Grief. Cambridge, MA: Harvard University Press, 1999.

Christie, Alastair. 'Unsettling the "Social" in Social Work: Responses to Asylum Seeking Children in Ireland'. Child Family Social Work 8.3 (2003): 223-231. doi:10.1046/j.13652206.2003.00287.x.

Couldrey, Marion, and Maurice Herson. Forced Migration Review. May 2015. Accessed 30 September 2016. http://www.fmreview.org/sites/fmr/files/FMRdownloads/en/ climatechange-disasters.pdf.

CSO - Central Statistics Office. Accessed 27 May 2016. http://www.cso.ie/en/media/ csoie/census/documents/census2ouprofile6/Profile_6_Migration_and_Diversity_ entire_doc.pdf.

Doras Luimni. 'Labour'Accessed 4 June 2016. http://dorasluimni.org/wp-content/uploads/pdf/publications/barrierstolabour.pdf.

Ejorh, Theophilus. 'Modern African Migrations to Ireland: Patterns and Contexts'. Journal of Ethnic and Migration Studies 38.4 (2012): 577-593. doi:10.1080/ 1369183x.2012.659123.

Fanning, Bryan, and Angela Veale. 'Child Poverty as Public Policy: Direct Provision and Asylum Seeker Children in the Republic of Ireland'. Child Care in Practice 10.3 (2004): 241-251. doi:10.1080/1357527042000244374.

Fanning, Bryan, Angela Veale, and Dawn O'Connor. Beyond the Pale: Asylum-Seeking Children and Social Exclusion in Ireland. Dublin: Irish Refugee Council, 2001.

Finn, C. 'High Court Rules Direct Provision Does Not Breach Human Rights'. The Journal, July. Accessed 30 September 2016. http://www.thejournal.ie/high-court-directprovision-human-rights-1780753-Nov2014/. 
Harild, Niels. 'Forced Displacement: A Development Issue with Humanitarian Elements'. Forced Migration Review. Accessed 19 June 2016. http://www.fmreview.org/ solutions/harild.html.

Justice Department, Final Report: June 2015. Dublin: Working Group, 2015.

Kenny, Kevin. 'Diaspora and Comparison: The Global Irish as a Case Study'. Journal of American History 90.1 (2003): 134. doi:10.2307/3659794.

Mac Éinrí, Piaras, and Allen White. 'Immigration into the Republic of Ireland: A Bibliography of Recent Research'. Irish Geography 41.2 (2008): 151-179. doi:10.108o/ o0750770802076943.

O'Grady, H. 'Barriers to the Labour Market for Refugees and Persons with Leave to Remain in Limerick'. Dorasluimni.org. 2008. Accessed 30 September 2016. http://dorasluimni.org/wp-content/uploads/pdf/publications/barrierstolabour.pdf.

O'Hearn, D. 'The End of Irish History? Reflections on the Celtic Tiger'.(2003): 34-55. doi:10.7228/Manchester/9780719062308.

Reception and Integration Agency (RIA) Ireland. Accessed 4 June 2016. http://www. ria.gov.ie/.

Ryan, Dermot A., Ciarán A. Benson, and Barbara A. Dooley. 'Psychological Distress and the Asylum Process'. The Journal of Nervous and Mental Disease 196.1 (2008): 37-45. doi:10.1097/nmd.obo13e31815fa51c.

Sheridan, A. '45o Beds in Limerick Pledged to Refugees'. Limerick Leader. September 2015. Accessed 30 September 2016. http://www.limerickleader.ie/news/local-news/ 196020/45o-beds-in-Limerick-pledged-to.html.

Shoumali, Anne. 2015. "Image Of Drowned Syrian, Aylan Kurdi, 3, Brings Migrant Crisis Into Focus". Nytimes.Com. http://www.nytimes.com/2015/o9/o4/world/europe/syria-boy-drowning.html?_r=o.

Thornton, L. '\#DirectProvision15: 15 Years of Direct Provision in Ireland'. Human Rights in Ireland. 2015. Accessed 30 September 2016.http://humanrights.ie/constitutionof-ireland/directprovision15-15-years-of-direct-provision-in-ireland.

Van Manen, Max. 'On the Epistemology of Reflective Practice'. Teachers and Teaching 1.1 (1995): 33-5o. doi:10.1080/135406095001010

Van Manen, Max. Researching Lived Experience: Human Science for an Action Sensitive Pedagogy. New York: sunY Press, 2006. 